\title{
Dimorphism in methane seep-dwelling ecotypes of the largest known bacteria
}

\author{
Jake V Bailey ${ }^{1,2}$, Verena Salman ${ }^{3}$, Gregory W Rouse ${ }^{4}$, Heide N Schulz-Vogt ${ }^{3}$, Lisa A Levin ${ }^{4}$ \\ and Victoria J Orphan ${ }^{2}$ \\ ${ }^{1}$ Department of Earth Sciences, University of Minnesota-Twin Cities, Minneapolis, MN, USA; ${ }^{2}$ Division of \\ Geological and Planetary Sciences, California Institute of Technology, Pasadena, CA, USA; \\ ${ }^{3}$ Max Planck Institute for Marine Microbiology, Bremen, Germany and ${ }^{4}$ Scripps Institution of Oceanography, \\ La Jolla, CA, USA
}

\begin{abstract}
We present evidence for a dimorphic life cycle in the vacuolate sulfide-oxidizing bacteria that appears to involve the attachment of a spherical Thiomargarita-like cell to the exteriors of invertebrate integuments and other benthic substrates at methane seeps. The attached cell elongates to produce a stalk-like form before budding off spherical daughter cells resembling freeliving Thiomargarita that are abundant in surrounding sulfidic seep sediments. The relationship between the attached parent cell and free-living daughter cell is reminiscent of the dimorphic life modes of the prosthecate Alphaproteobacteria, but on a grand scale, with individual elongate cells reaching nearly a millimeter in length. Abundant growth of attached Thiomargarita-like bacteria on the integuments of gastropods and other seep fauna provides not only a novel ecological niche for these giant bacteria, but also for animals that may benefit from epibiont colonization.
\end{abstract}

The ISME Journal (2011) 5, 1926-1935; doi:10.1038/ismej.2011.66; published online 23 June 2011

Subject Category: microbial ecology and functional diversity of natural habitats

Keywords: Beggiatoa; budding; epibiont; sulfur bacteria; Thiomargarita; Thioploca

\section{Introduction}

The bacterial domain includes representatives with a variety of cell shapes (Young, 2006) and types of cell division (Angert, 2005). Bacterial cell morphologies can provide selective advantages ranging from increased motility to decreased predation susceptibility (Young, 2006). The enormous size of the sulfide-oxidizing Gammaproteobacterium, Thiomargarita namibiensis, is thought to provide it with the ability to store nitrate for months, persisting in environments in which availability of the primary terminal electron acceptor oxygen, or the alternative acceptor nitrate, can be temporally and spatially variable (Schulz and Jørgensen, 2001; Schulz, 2006). However, the influence of cell morphology on the ecophysiology of these giant sulfur bacteria may not be limited to their large size.

Thiomargarita was first described in 1999 from diatom-rich oozes in the Benguela upwelling system off West Africa (Schulz et al., 1999). The originally described species T. namibiensis occurs primarily as linear chains of spherical cells enclosed in a mucous

Correspondence: JV Bailey, Department of Earth Sciences, University of Minnesota-Twin Cities, 310 Pillsbury Drive SE, Minneapolis, MN 55455, USA.

E-mail: baileyj@umn.edu

Received 20 September 2010; revised 28 March 2011; accepted 3 May 2011; published online 23 June 2011 sheath (Schulz et al., 1999), though other morphotypes have since been described (Schulz, 2006; Gutzke, 2007). In 2005, Thiomargarita-like bacteria that undergo reductive cell division resulting in symmetrical clusters of up to 16 cells were discovered at hydrocarbon seeps from the Gulf of Mexico (Kalanetra et al., 2005; Bailey et al., 2007). Other Thiomargarita-like bacteria have also been obtained from mud volcanoes in the Barents Sea (de Beer et al., 2006) and the Eastern Mediterranean Sea (Girnth et al., 2011). During a 2009 cruise aboard the R/V Atlantis, we observed a population of Thiomargarita-like cells in cores and on carbonate rock samples collected with the DSV Alvin at methane seeps associated with fault scarps, landslides and mud mounds (Bohrmann et al., 2002) at water depths of $\sim 990-1600 \mathrm{~m}$ along the Pacific margin of Costa Rica. Within the Thiomargarita-like population present at Costa Rica margin seeps are canonical free-living, solitary and reductively dividing forms, as well as cells exhibiting an attached, presumptive dimorphic life cycle that we describe here. Similar populations of free-living and attached Thiomargarita-like cells were observed in Hydrate Ridge (off Oregon, USA) seep settings in 2010. The observation of dimorphic forms at multiple localities suggests that a dynamic morphology has an important role in the ecology of vacuolate sulfur bacteria in seep settings. 


\section{Materials and methods}

Sample collection and microscopy

Samples were obtained during a research expedition to the Pacific margin of Costa Rica aboard the R/V Atlantis in February-March 2009 (AT15-44) and during a follow-up cruise to the same sites in January 2010 (AT15-59). Push cores, samples of authigenic carbonate and associated macro- and megafaunal animals were collected from methane seeps associated with mud mounds and fault scarps at Mound $11\left(1000-1025 \mathrm{~m}, 8^{\circ} 55.4^{\prime} \mathrm{N}, 84^{\circ} 18.24^{\prime} \mathrm{W}\right)$, Mound $12\left(990-1100 \mathrm{~m}, 8^{\circ} 55.8^{\prime} \mathrm{N}, 84^{\circ} 18.75^{\prime} \mathrm{W}\right)$, Jaco Scarp (1775-1850 m, $\left.9^{\circ} 7.00^{\prime} \mathrm{N} 84^{\circ} 50.51^{\prime} \mathrm{W}\right)$ and Mound Quepos (1030-1179m, $8^{\circ} 58.09^{\prime} \mathrm{N}, 84^{\circ}$ $\left.37.95^{\prime} \mathrm{W}\right)$ using the DSV Alvin. Additional collections of living gastropods with attached sulfur bacteria were made during AT 15-68 at Hydrate Ridge North $\left(44^{\circ} 40^{\prime} \mathrm{N} 1255.8^{\prime} \mathrm{W}\right)$ and Hydrate Ridge South $\left(44^{\circ} 34.1^{\prime} \mathrm{N} 125^{\circ} 9.1^{\prime} \mathrm{W}\right)$.

During the research expedition, a Leica S8 APO stereo-microscope coupled with a Canon Powershot 9 (Leica, Buffalo Grove, IL, USA) was used to observe and image freshly collected free-living cells, as well as those cells attached to byssal threads, shells and other benthic substrates. Cells that were budding at the time of collection were followed for a 10-day duration of the cruise and imaged on a daily basis in order to document bud detachment. In the laboratory, an Olympus SZX16 stereo-microscope and an Olympus BX51 compound microscope equipped with an Olympus DP72 color camera were used to obtain higher resolution images of these cells and attachment substrates (Olympus, Tokyo, Japan).

\section{Electron microscopy}

Gastropods covered with attached Thiomargarita-like sulfur bacteria were preserved in Karnovsky's fixative (Karnovsky, 1965) before undergoing ethanol series dehydration (25\%, 50\%, 75\%, 90\%, 99\%) in artificial seawater/ethanol mixtures for $30 \mathrm{~min}$ each. The bacteria-covered gastropod shells were then dried in a Tousimis Model 780A Critical-Point Dryer (Tousimis, Rockville, MD USA) before being imaged uncoated with a Hitachi TM-1000 tabletop scanning electron microscope (Hitachi, Tokyo, Japan).

For transmission electron microscopy imaging, samples were fixed with Karnosky's fixative solution and after three times washing with artificial seawater, the samples were post fixed with $1 \% \mathrm{OsO}_{4}$ for $1 \mathrm{~h}$. Following three times rinsing with $\mathrm{H}_{2} \mathrm{O}$, the samples were dehydrated in a graded series of ethanol (see above). The samples were embedded in Epon 812 resin (Electron Microscopy Sciences, Fort Washington, PA, USA). Ultrathin sections (65 nm) were produced using a Reichert UltraCut S Ultramicrotome (Reichert Technologies, Depew, NY, USA) and stained with uranyl acetate and lead citrate before being examined with a JEOL 1200EX electron microscope (JEOL Inc., Tokyo, Japan).
$16 S$ ribosomal RNA (16S rRNA) gene sequencing Free-living Thiomargarita-like cells from Costa Rica and Namibia were removed from the sediment (Salman et al., 2011). The novel attached morphotype from Costa Rica were carefully scraped off byssal threads with two needles and the detached cells were removed from the sample as described above. Individual cells, that is, free-living cells and formerly attached cells sometimes showing distal budding, were washed in artificial seawater, photographed under the microscope and subsequently used for performing single-cell 16S rRNA PCR methods described elsewhere (Salman et al., 2011). The specific primer for Thiomargarita-related organisms, VSO233F, 5'-CCTATGCCGGATTAGCTTG-3' (Escherichia coli 16S rRNA position 233-251, Salman et al., 2011), was combined with the universal primer ITSReub, 5'-GCCAAGGCATCCACC-3' (E. coli 23S rRNA position 23-38; Cardinale et al., 2004). Some attached cells did not reveal any PCR product with these primers, thus another specific forward primer was developed based on Thiomargarita sequences from the public databases: VSO360F, 5'-GGAATATT GGACAATGGGC-3' (E. coli 16S rRNA positions 361-379, developed in this study), which was used in combination with primer VSO1300R, 5'-ATCCGGA CTACGAGTAG-3' (E. coli 16S rRNA position 1291-1307; Salman et al., 2011).

The amplification products were analyzed by agarose gel electrophoresis, bands of $\sim 1750 \mathrm{bp}$ length (and $\sim 940$ bp length with the other primer pair) were excised and DNA was purified with a gel extraction kit (Qiagen, Hilden, Germany). PCR products were sequenced directly using the Big Dye Cycle Sequencing Kit and analyzed on the ABI Prism Genetic Analyzer 3130x (Applied Biosystems, Carlsbad, CA, USA). The seven 16S RNA Thiomargarita-affiliated sequences have been submitted to the DDBJ/EMBL/GenBank databases. The accession numbers are FN811658-FN811664. The internal transcribed spacer region (spacer region between 16S rRNA and 23S rRNA as part of the PCR product when using primer ITSReub) was removed before further analysis of sequences.

\section{Phylogenetic tree reconstruction}

The phylogenetic affiliation of the retrieved sequences was inferred with the ARB software package (Ludwig et al., 2004) based on release 95 of the SILVA SSURef database (Pruesse et al., 2007). The alignment of all sequences was automatically performed with the integrated aligner and checked manually afterwards, taking into account the secondary structure of the $16 \mathrm{~S}$ rRNA molecule. For tree reconstruction, a total of 90 nearly full-length sequences, including representatives of the Gammaand Deltaproteobacteria, were used. Trees were calculated including nucleotide positions between 279 and 1463 (according to E. coli numbering) and performing neighbor joining, maximum parsimony 
and maximum likelihood analyses, each with the application of $0 \%, 30 \%$ and $50 \%$ positional conservatory filters excluding highly variable regions. Partial sequences (AY632420, AF129012, FN811664) were inserted into each of the reconstructed trees by parsimony criteria without allowing changes in the overall tree topology. A consensus tree was manually produced based on the maximum likelihood tree calculated with a 30\% filter using an approach described in (Peplies et al., 2008). The branching patterns of all trees were compared and multifurcations were introduced at nodes where the exact tree topology could not be clearly resolved (Peplies et al., 2008). The tree presented in Figure 5 shows a subset of the sequences originally used for calculation. Neighbor-joining and maximum likelihood trees are included in the supplement for comparison (Supplementary Figure S1 and S2).

\section{Results and discussion}

Occurrence of Thiomargarita-like bacteria

Free-living Thiomargarita-like cells were observed in sulfidic sediments at several mud mounds and associated methane seeps (Figure 1a). As in sediments from off Namibia (Schulz et al., 1999), and in the Gulf of Mexico (Kalanetra et al., 2005), freeliving sulfur bacteria off Costa Rica resembling Thiomargarita were most abundant in white and gray mat associated sediments in the uppermost $3 \mathrm{~cm}$ beneath the sediment/water interface. At some localities, cell populations consisted primarily of single Thiomargarita-like cells mixed with large Beggiatoa-like filaments (Figure 1a), whereas at other locations, symmetrical cell clusters (not shown) predominated in gray flocculant material at the seabed. These cell clusters contained 2, 4, 8 and 16 cells, similar to those produced by reductive division in Thiomargarita sp. from the Gulf of Mexico (Kalanetra et al., 2005). In the vicinity of these sediments, rich in free-living spherical Thiomargarita-like cells, thin films of microbial biomass were found attached to methane-derived authigenic carbonates (Figure 1b), byssal threads of the mussel Bathymodiolus spp. (Figure 1c), fragments of organic detritus, and most commonly, the integuments of seep-endemic invertebrates (Figures 2a-c). Microscopic examination of this benthic biofilm material revealed densely packed attached sulfur-storing vacuolated cells that closely resemble Thiomargarita, but with most cells elongated into a stalk-like form. Individual cells occasionally reached nearly $700 \mu \mathrm{m}$ in length, but average elongate cells were $338 \pm 169 \mu \mathrm{m}$ long (Supplementary Figure S3). These elongate cells were observed to bud spherical Thiomargarita-like cells from their unattached pole (Figures 3 and 4). The attached poles of the elongate cells ranged from rounded (Figures 3 and 4) to a heavily tapered, and sometimes extruded shape, forming a short appendage

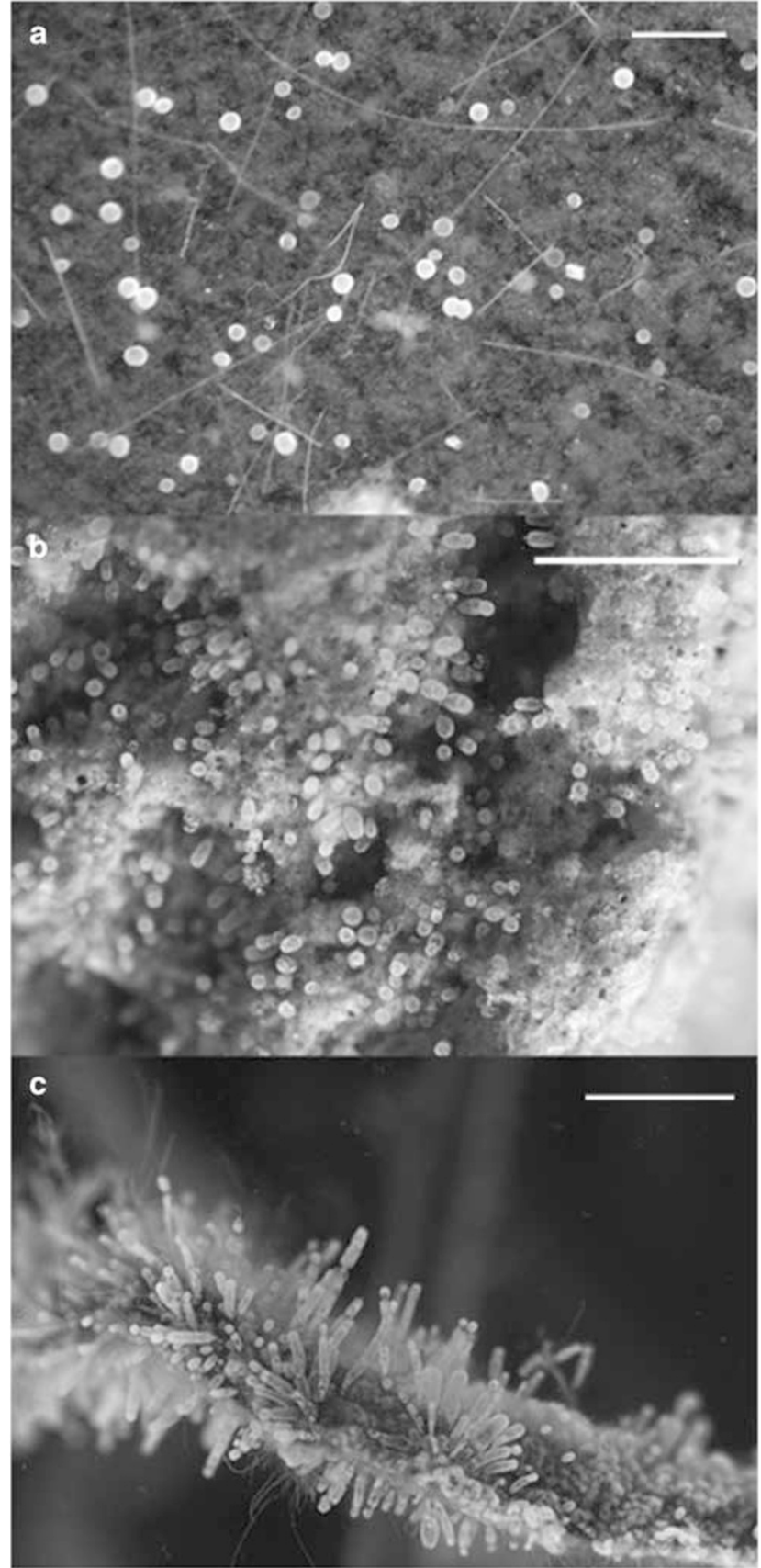

Figure 1 Vacuolate sulfide-oxidizing bacteria are abundant on a variety of substrates along the Costa Rica Margin including (a) free-living Thiomargarita-like cells and large Beggiatoa-like filaments inhabiting sulfidic sediments; (b) slightly elongate Thiomargarita-like morphotypes attached to authigenic carbonates; and (c) elongate Thiomargarita-like cells attached to Bathymodiolus mussel byssal threads. Scale bars represent $500 \mu \mathrm{m}$.

(Figure 4c). Both the attached elongate cells and the buds consisted of a single thin layer of sulfur globule-containing cytoplasm surrounding a single large vacuole (Figure $3 \mathrm{~d}$ and transmission electron microscopy observations not shown)—a basic cell structure that they share with all previously described Thiomargarita ecotypes (Schulz et al., 1999; 


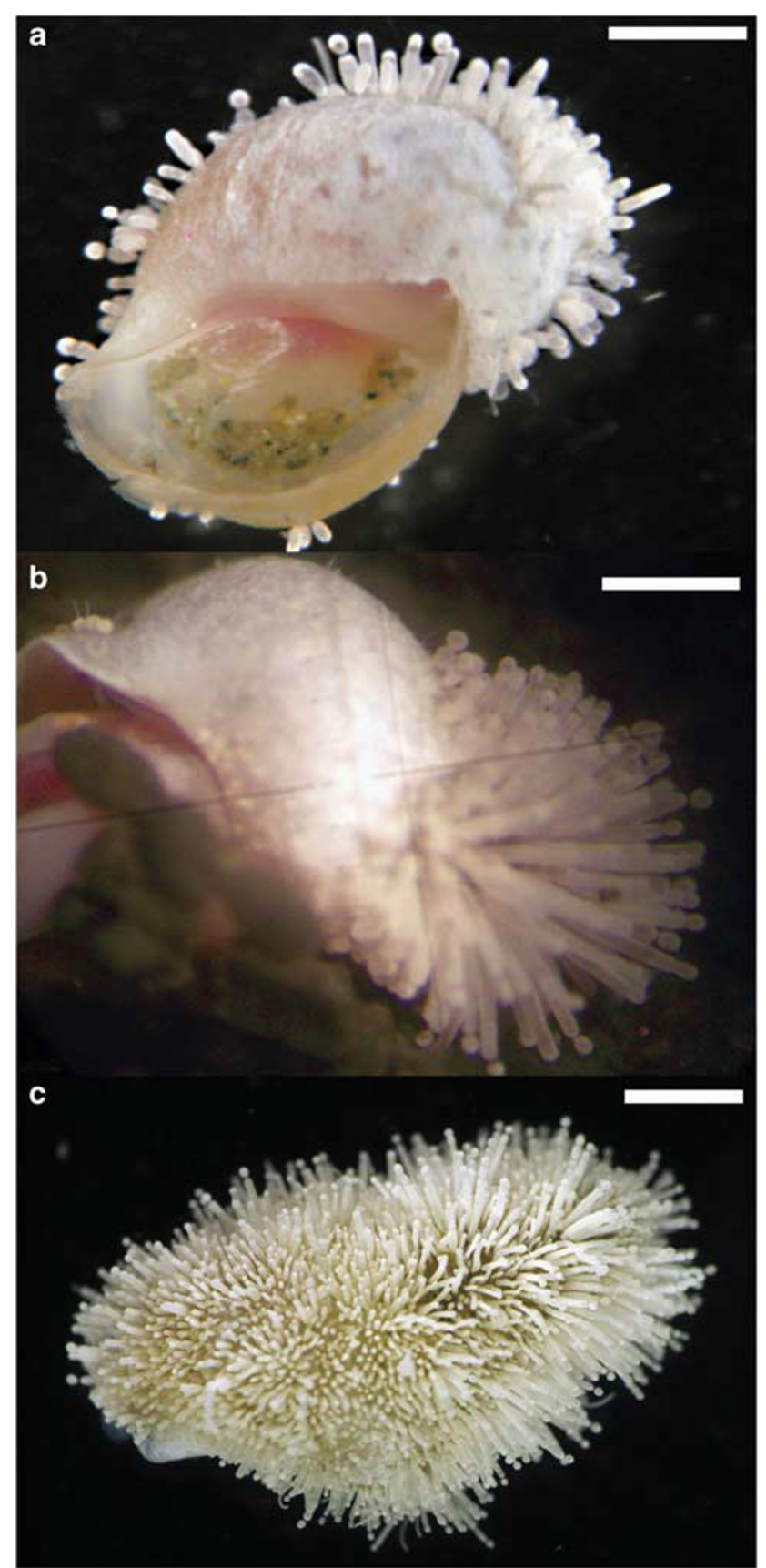

Figure 2 (a-c) The shells of living gastropods (Provanna laevis) from the Costa Rica margin and the Cascadia margin (Hydrate Ridge) are colonized by attached, elongate Thiomargarita-like cells. Scale bars represent $\sim 1 \mathrm{~mm}$.

Kalanetra et al., 2005; Schulz, 2006). Elongate morphotypes were not observed in the unattached free-living state. We hypothesize that the attached, budding types, and at least some of the free-living cells, represent not different species, but different stages of a reproductive developmental cycle. We evaluated this hypothesis by directly observing the budding forms after collection. Furthermore, we analyzed the 16S rRNA gene sequences of the new, attached morphotypes, as well as of the free-living canonical morphotypes. Evidence for a developmental relationship between the attached cells and free-living spherical cells was provided by direct observation of buds formed at the time of collection completely detaching from budding parent cells at a rate of approximately one detachment in 300 budding cells over a $24 \mathrm{~h}$ period (12 in approximately 3600 individuals observed), demonstrating that the budded daughter cells are indeed being released into the surrounding environment (Figures 3b, c, f). Fully detached, budded daughter cells were morphologically identical to free-living, spherical sulfur bacteria in surrounding sediments and both have similar cell diameters; $71 \pm 22 \mu \mathrm{m}, \quad n=40$ versus $88 \pm 14 \mu \mathrm{m}, \quad n=37$. The morphological similarity of the released buds to the free-living Thiomargarita-like cells in the surrounding sediments suggests the possibility that at least some of the latter population results from the released spherical buds. However, morphology can be misleading, particularly with respect to the phylogenetic identification of vacuolated sulfur bacteria. For example, marine filaments with a Beggiatoa-like morphology, that have similar filament diameters and were collected from the same locality, can be quite divergent with respect to their phylogenetic positions (Teske et al., 1999; Mußmann et al., 2007). The observations that the attached elongate cells are found on hard substrates that are physically separated by sediments that contain spherical, free-living cells, and that elongate cells are never observed in the free-living populations, strongly suggests that at least some of the free-living population includes the spherical offspring of the attached morphotypes. In addition, the assertion that the life cycle is initiated by the attachment of spherical cells is supported by the observation of attached spherical cells that are just beginning elongation (Supplementary Figure S4), along with the spectrum of elongation morphologies from sphere, to prolate spheroid, to increasingly longer cylindrical cells occurring in close proximity (Figure 4d). However, the percentage of free-living cells that represent the progeny of attached budding forms remains unclear.

Sequence comparisons of individual cells indicated that Costa Rica margin seeps harbor not just one, but at least three distinct phylogenetic clusters. The relatedness of the organisms in this study to Thiomargarita namibiensis and Thiomargarita sp. from the Gulf of Mexico is apparent from the phylogenetic tree produced by sequencing individual representatives from Costa Rica and additional specimens from Namibia (Figure 5). The sequences published before this study constitute the closest relatives to at least five sequences obtained in this study. Although some sequences of free-living and attached morphotypes are closely related to previously published Thiomargarita spp. (Kalanetra et al., 2005, Schulz et al., 1999), two sequences (COS001 and COS016) each formed a separate branch that did not cluster within the Thiomargarita 


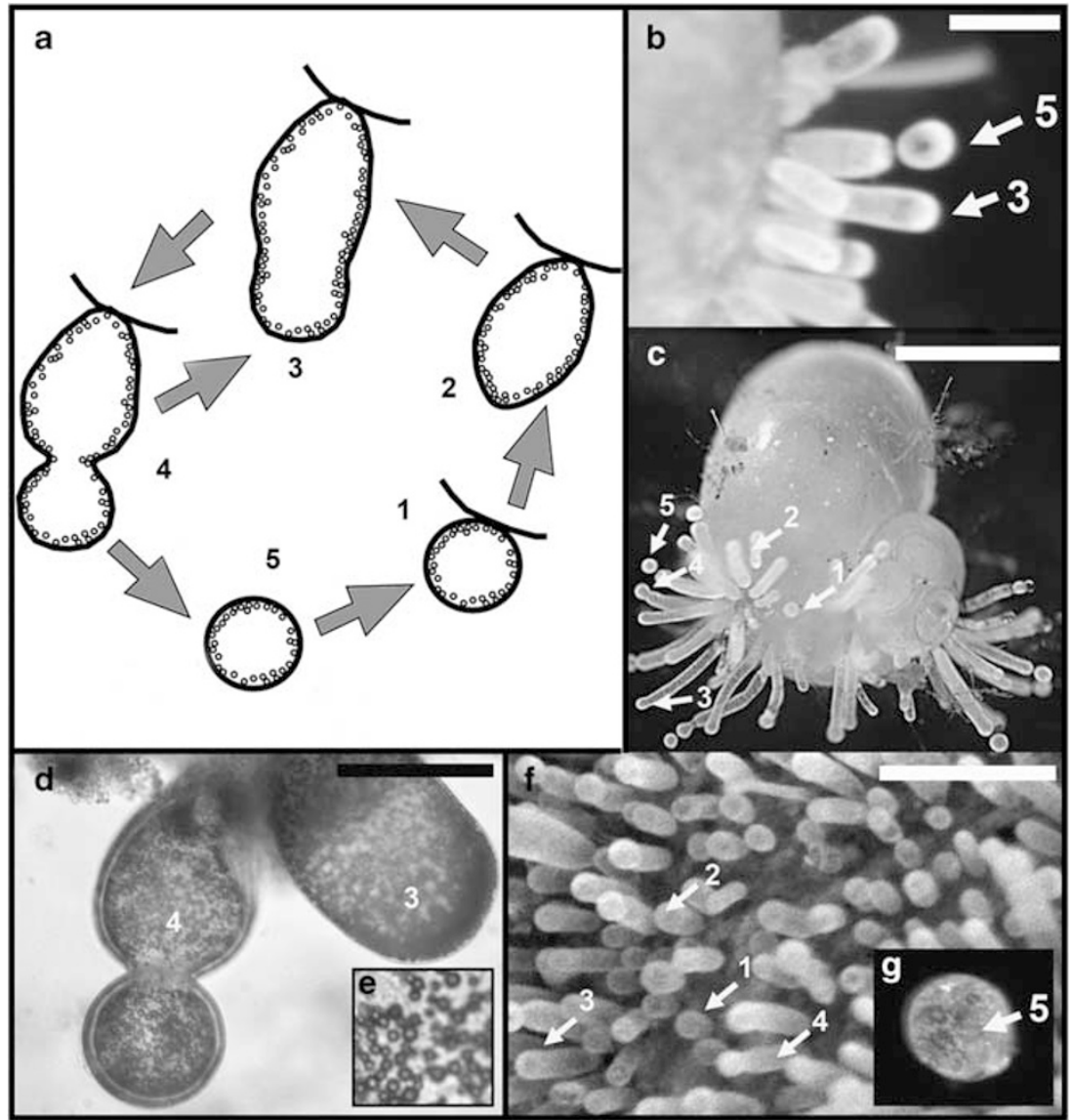

Figure 3 An apparent reproductive developmental cycle in attached sulfur bacteria (a) appears to begin with the attachment of a spherical cell to a solid substrate (arrows 1), followed by elongation to a stalked form (arrows 2), initial bud formation (arrows 3) and finally budding (arrows 4) to produce a spherical daughter cell (arrows 5). (b, c) Attached sulfur bacteria on a gastropod shell. (d, e) Detail of attached cell and intracellular sulfur globules. (f) Bacteria attached to mussel byssal threads. (g) Budded Thiomargarita-like cell was observed to undergo complete detachment from the mother cell between 12 and $20 \mathrm{~h}$ after collection. After bud detachment, the elongate mother cell $(\mathbf{a} 4 \rightarrow 3)$ can continue to produce additional buds. Scale bar in $\mathbf{b}=350 \mu \mathrm{m} ; \mathbf{c}=1 \mathrm{~mm} ; \mathbf{d}=200 \mu \mathrm{m} ; \mathbf{f}=300 \mu \mathrm{m}$.

clade. The paraphyletic relationship of the retrieved $16 \mathrm{~S}$ rRNA gene sequences surely complicates identification of cells based on morphology. Nomenclature for Thiomargarita-like cells and other vacuolate sulfur bacteria can be confusing, as some canonical genera include paraphyletic taxa. However, the taxonomy of the colorless sulfur bacteria, including the novel morphotypes identified in this study, was recently revisited by Salman et al. (2011).

Sequences in the three clusters represent either attached, free-living or paired free-living/attached morphotypes (Figure 5). Some sequences showed $>99 \%$ similarity between attached and free-living morphotypes (Table 1) that may represent different developmental stages of the same organism, as the $<1 \%$ difference is within the range of experimental error. Alternatively, these cells could represent closely related phylotypes that superficially resemble parts of the putative dimorphic life cycle, but do not represent the direct progeny of the attached cells. The disparity could be caused by natural variability within the seep population coupled with the relatively low number of sequenced specimens, and the inherent limitations of sampling a deepwater site via submersible, thereby possibly missing directly corresponding mother and daughter cells. It is also unclear whether the reductively dividing free-living sulfur bacteria present in nearby sediments exhibit attachment or dimorphism as part of their life cycle(s).

\section{Ecological significance of dimorphism}

Reproductive dimorphism is known in the Alphaproteobacteria, such as Caulobacter crescentus, whose parent cells are stalked, and the daughter cells are vibroid-but in those organisms the daughter cells are actively motile (Brun and Janakiraman, 2000; Poindexter, 2006). In the sulfur bacteria detected here, the daughter cells are not yet known to be actively motile-though an inconspicuous sporadic slow rolling motility has been observed in different, spherical sulfur bacteria from Namibia (Salman et al., 2011). In addition, freeliving daughter cells can be readily transported by 


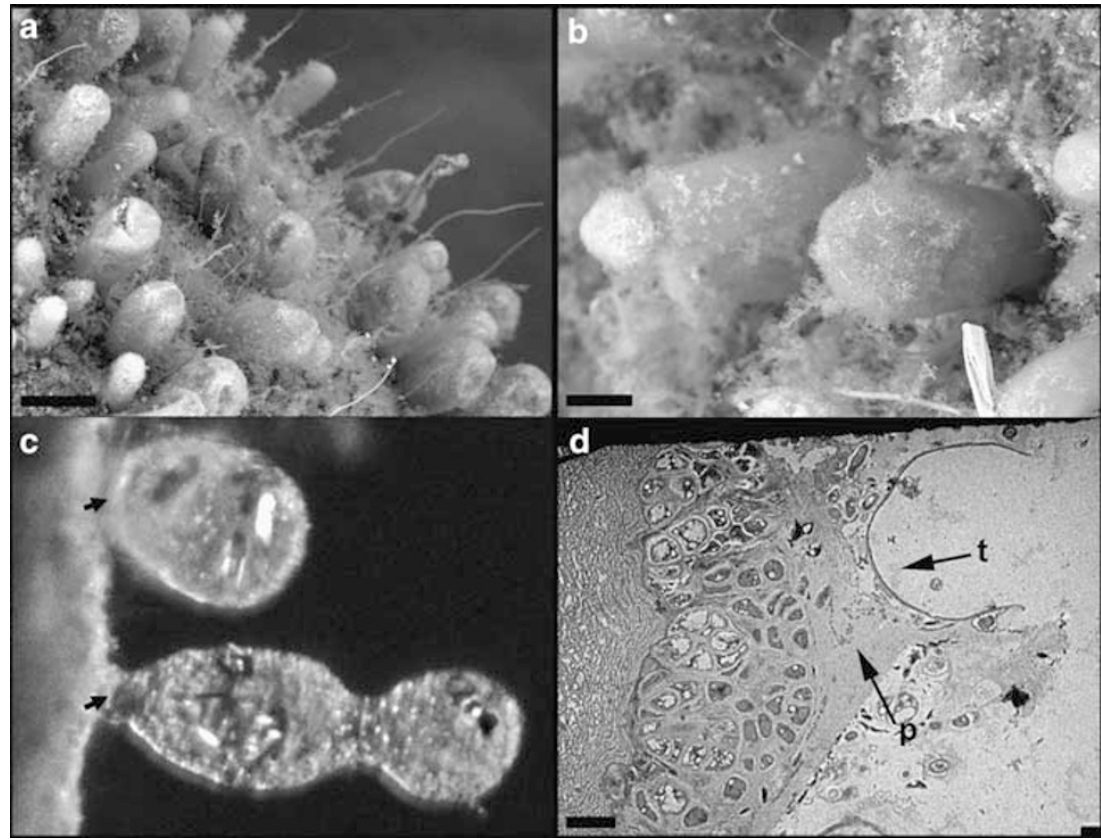

Figure 4 Attached sulfur bacteria. (a, b) Densely packed Thiomargarita-like cells on gastropod shell co-occur with attached filamentous bacteria. Scale bar in $\mathbf{a}=30 \mu \mathrm{m} ; \mathbf{b}=20 \mu \mathrm{m}$. (c) Particularly during early stages of attachment and elongation they have rounded bases where they are attached to benthic substrates. As the cell elongates, the base of the cells becomes tapered. In some specimens, a small appendage formed by extrusion of the cell ultrastructure is present. (d) Transmission electron micrograph of vacuolated Thiomargaritalike cells (t) attached to plaque (p) and mucous occupied by smaller filamentous bacteria. This material surrounds the Bathymodiolus mussel byssus. Scale bar $=2 \mu \mathrm{m}$.

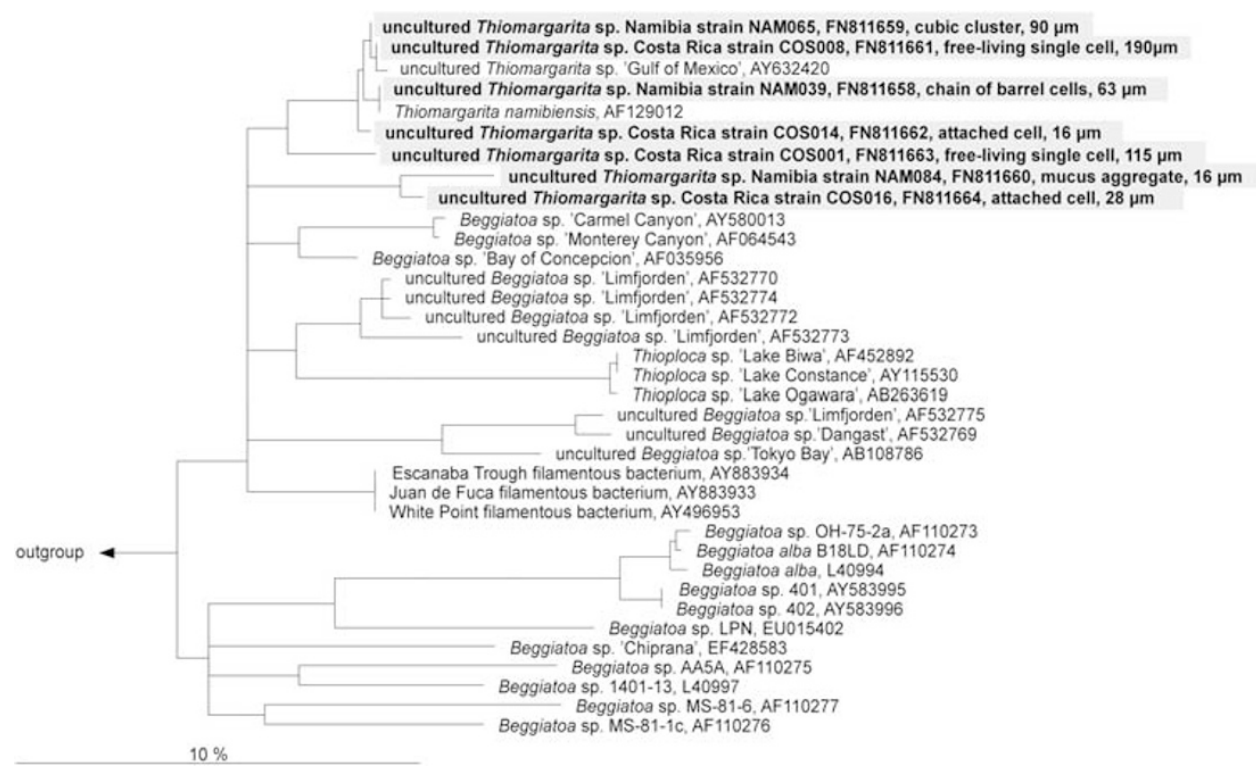

Figure 5 Phylogenetic tree of gammaproteobacterial 16S rRNA gene sequences showing sequences of different morphotypes from Costa Rica (COS) and Namibia (NAM) in gray and their affiliation to previously published Thiomargarita spp. These sequences are shown within the context of the broader clade of conspicuous sulfide-oxidizing Gammaproteobacteria. Of each newly sequenced cell the morphology and diameter is indicated. In attached forms, the widest diameter of the attached basal body is reported. The scale bar represents $\sim 10 \%$ sequence divergence.

bottom currents. Broken, transported and re-deposited clasts of methane-derived authigenic carbonate edifices observed on the collection cruises, as well as evidence for local sediment winnowing, record the presence of such currents at the sites where the attached Thiomargarita-like morphotypes occur. On detachment, buds may also attach to substrates directly adjacent to the mother cell. This process is 
Table 1 Levels of 16S rRNA gene sequence identities of nearly full-length sequences from Thiomargarita-like cells from the COS and NAM along with partial sequences of formerly described T. nam. and T. GOM from the Gulf of Mexico as reference species

\begin{tabular}{lccccccc}
\hline & NAM065 & COS008 & T. GOM & NAM039 & T. nam. & COS014 & COS001 \\
\hline NAM065 & & & & & & \\
COS008 & 99.8 & & & & & \\
T. GOM & 99.7 & 99.8 & & & & \\
NAM039 & 99.5 & 99.2 & 99.8 & & & \\
T. nam. & 99.1 & 98.7 & 99.1 & 100 & & \\
COS014 & 99.4 & 99.4 & 99.1 & 99.3 & 98.9 & & \\
COS001 & 96.6 & 96.5 & 95.7 & 96.4 & 94.9 & 96.8 & \\
NAM084 & 95.3 & 95.3 & 92.4 & 95.3 & 92.4 & 95.2 & 94.4 \\
COS016 & 95.1 & 95.1 & 95.1 & 95 & 95 & 94.8 & 93.8 \\
\hline
\end{tabular}

Abbreviations: 16S rRNA, 16 ribosomal RNA; COS, Costa Rica margin; NAM, Namibia; T. GOM, Thiomargarita sp. Gulf of Mexico; T. nam., Thiomargarita namibiensis.

known to occur in some prosthecate Alphaproteobacteria and would explain the observation that mats of attached Thiomargarita-like sulfur bacteria are often densely packed and frequently exhibit more than one developmental stage on the same substrate (Figure $3 \mathrm{~b}$ ). Alternatively, certain cells in the mat may simply have slower elongation and budding rates than others.

The factors responsible for initiating attachment, elongation and budding in these bacteria are not fully understood because Thiomargarita and its vacuolated relatives have yet to be cultivated in the laboratory. However, comparisons with other organisms that exhibit similar behaviors may provide clues. Attachment to solid substrates is also known in other Gammaproteobacteria, including the closely-related marine, vacuolated Thiothrix-like bacteria (Kalanetra et al., 2004, Kalanetra and Nelson 2010). Indeed, attached filamentous Thiothrixlike filaments sometimes co-occur with the attached Thiomargarita-like cells described here. Attachment provides stabilization of a parent cell under conditions in which it can produce daughter cells for dispersal to other potential habitats via bottom currents. Presumably, stabilization of reproductively active sulfide-oxidizing cells over zones of sulfide enrichment would be more important in advective seep habitats where sulfide generated by the anaerobic oxidation of methane or vented directly from subsurface fluids is more localized than the sulfide generated by sulfate reduction in upwelling regions (Linke et al., 2005).

Budding is known in Thiothrix-like filaments (Kalanetra et al., 2004), in certain low-GC grampositive bacteria, cyanobacteria, planctomycetes and prosthecate Alphaproteobacteria (Angert, 2005) among others. In prosthecate bacteria, it is the stalked parent cell that undergoes budding, suggesting that perhaps elongation enhances dispersal of daughter cells. However, elongation is apparently not a prerequisite to budding in attached Thiomargarita-like cells, as division of attached but not elongated cells, or slightly elongated cells, was observed on a handful of substrates (Figure 1b). Access to scarce metabolites may instead drive elongation in attached sulfur bacteria. Cell elongation in Caulobacter crescentus is thought to enhance the uptake of phosphorous from the environment by increasing the surface area-to-volume ratio of a cell (Poindexter, 1984). Thiomargarita namibiensis, which lives in sediments beneath upwelling zones, sequesters phosphorous as intracellular polyphosphate granules (Schulz and Schulz, 2005). In seep settings, phosphorous is less available than in an upwelling environment (Joye et al., 2004; Linke et al., 2005). Thus, cell elongation in seep-dwelling sulfur bacteria may provide for enhanced phosphorous uptake as it does in the Alphaproteobacteria. Nutrient uptake and adenosine triphosphate synthesis scales with cell surface area, and Thiomargarita functions at a relatively low level of metabolic power per gene (Lane and Martin, 2010). An elongate cell has a higher surface area-to-volume ratio than a spherical cell of the same volume (Young, 2006). For example, if a cell was assumed to be a cylinder capped with hemispherical ends, $300 \mu \mathrm{m}$ in length and $80 \mu \mathrm{m}$ in diameter, the cell would have a $38.5 \%$ greater surface area-to-volume ratio (0.054) over a sphere with the same volume (0.039). The larger a Thiomargarita cell grows, the larger its potential store of nitrate, but at the cost of decreasing its surface areato-volume ratio. Growth of a cell into an elongate form, as opposed to simply expanding the sphere volume, minimizes the decrease in surface area-tovolume ratio that accompanies growth. Reductive cell division, which is observed in free-living Thiomargarita-like cells at this site, also effectively increases surface area while maintaining a constant nitrate-storage volume, although by producing smaller cells.

The elongation of budding cells may also allow attached cells greater access to the terminal electron acceptors, oxygen and nitrate. It is not known whether attached and free-living reductively dividing Thiomargarita-like bacteria represent different stages within the same life cycle. However, one possibility is that elongation increases surface area in attached cells that have access to nitrate and can readily enlarge, whereas reductive division apportions stored nitrate into smaller, easily dispersible 


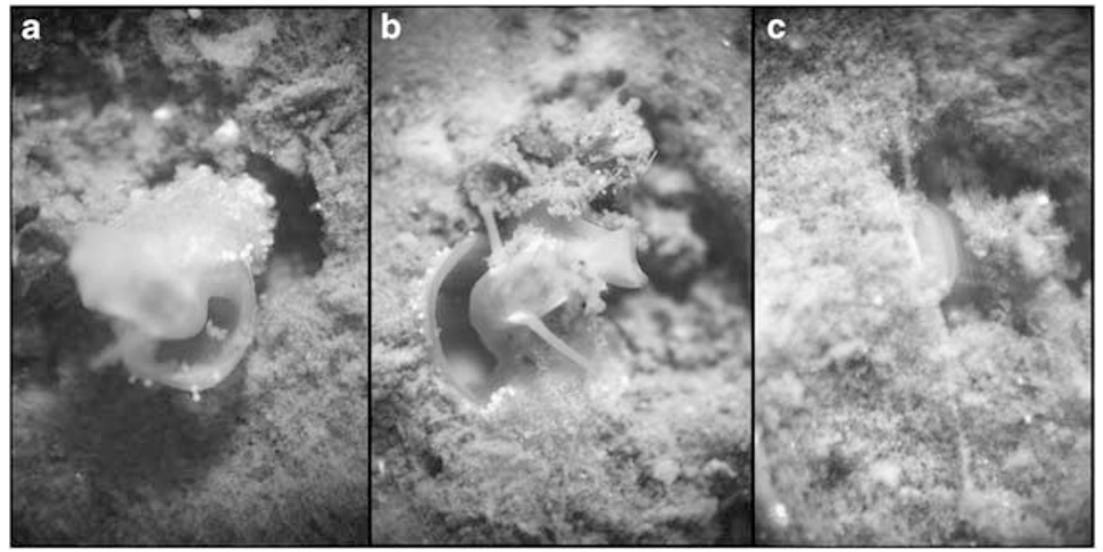

Figure 6 The gastropod Provanna laevis burrows into sulfidic mud in a collection container, (a) first digging a burrow, (b) then occupying the burrow with its carapace oriented downward, which exposes the population of attached sulfur bacteria to sulfidic conditions. (c) The head of the gastropod remains partially exposed above the sediment/water interface.

cells with higher surface area-volume ratios when nitrate availability is limited. Closely related vacuolate sulfur bacteria resembling Beggiatoa and Thioploca can actively move along gradients between sulfide and terminal electron acceptors (Nelson et al., 1986; Huettel et al., 1996). In seep settings, alternating conditions of access to electron donor and acceptor can be introduced by brine flows (Girnth et al., 2011), changing currents, and heterogeneous pore fluid advection, exposing populations of sulfur bacteria to alternating conditions of high sulfide, nitrate and oxygen fluxes. Elongation in sessile bacteria may provide cells with a larger surface area for more efficient uptake of spatially segregated metabolites, under the fluctuating and heterogeneous fluxes of $\mathrm{O}_{2}, \mathrm{NO}_{3}^{-}$and $\mathrm{H}_{2} \mathrm{~S}$ measured in Costa Rica margin sediments (Linke et al., 2005). In some freshly collected samples, elongate cells possess a visibly marked increase in sulfur globules at the distal end of the cell. The apical, sulfurenriched region is the site of bud formation. These sulfur resources might be incorporated into the budding offspring, providing an initial energy reserve for the free-living state. Alternatively, the irregular distribution of sulfur globules may be driven by the local geochemical environment, where the observed sulfur accumulation at the apical end of the cell is linked to close contact with either oxygenated, or sulfidic waters, depending on the orientation of the cell. However, this explanation seems less likely, as cells attached to opposite sides of byssal threads also showed apical sulfur enrichment in cells oriented in opposite directions.

\section{Metazoan-bacterial interactions}

The attachment of newly detected sulfur bacteria to benthic substrates also has potentially important implications for metazoan ecology at seeps. Elongate sulfur bacteria were found attached to byssal threads of Bathymodiolus spp. (Mytilidae, Bivalvia), the carapace of a Yeti crab specimen (Kiwa sp.), the shells of several species of gastropod including Provanna laevis, Hyalogyrina sp. and Pyropelta spp., and the limpet Lepetodrilus sp. These gastropod shells were commonly covered with thick mats of attached elongate sulfur bacteria (Figure 2). Interestingly, bacteria-covered Provanna collected from Hydrate Ridge in 2010 exhibited an unusual behavior that may benefit the attached sulfideoxidizing bacteria. When placed in a container with seawater overlying sulfidic sediments, they were observed to either climb to the uppermost portion of the jar and maintain a position adjacent to the small air headspace $(n=4)$, or actively dig a burrow into the sulfidic sediments $(n=8)$ and subsequently inverting themselves, so that their shell and attached bacteria were positioned within the freshly dug burrow (Figure 6). Gastropods removed from the burrows with forceps repeatedly re-established their burrows and inverted positions $(n=6)$. Epibiontbearing invertebrates are known to migrate between oxygenated and sulfidic sediment pore waters as a means of supplying symbionts with the metabolic substrates required for sulfide oxidation (for example, Ott et al., 1991), and a similar behavior may be on display here. However, this behavior and association with seep invertebrates is apparently not a requirement for growth of the attached Thiomargaritalike cells, as these bacteria are sometimes found on stabilized mineral and detrital substrates such as carbonate rocks. The impetus for gastropods to exhibit this behavior that potentially exposes them to predation while lying inverted with their soft parts exposed remains unclear. The bacteria may reduce the animal's exposure to hydrogen sulfide as is thought to occur in other invertebrates (Alain et al., 2002). These species of gastropods are not known to contain sulfide-oxidizing endobionts. Attached bacteria may also serve as food source for grazing gastropods, as occurs in some other animal/ epibiont symbioses (for example, Ott et al., 1991; Zbinden and Cambon-Bonavita, 2003; Gillian and Dubilier, 2004; Dattagupta et al., 2009), although 
these gastropods are seemingly incapable of consuming the bacteria attached to their own shells.

At Costa Rica seep settings, attached sulfur bacteria are rare on rocks and shells with large surface areas. The substrates most well colonized by the cells are those with low surface areas such as small shells and mussel byssal threads. When they do occur on larger substrates, they are found in small isolated patches or within small crevices. The apparent absence of attached bacteria on Bathymodiolus mussel shells, Lamellibrachia tubes, and most carbonate rocks suggests that they may be limited to surfaces that are not subject to intense shearing forces or grazing by gastropods. The shells and carapaces of the grazers themselves and cryptic habitats, such as mussel byssal threads, may offer a refuge from consumers. Alternatively (or additionally), the availability of sulfide, nitrate and oxygen may make certain microenvironments more conducive to colonization by attached sulfur bacteria. High oxygen and nitrate fluxes, primarily driven by bacterial oxidation of sulfide (781 and $700 \mu \mathrm{mol} \mathrm{cm} \mathrm{cm}^{-2}$ per year, respectively), have been reported at the collection sites, but these fluxes vary by up to three orders of magnitude over distances of tens of centimeters as a result of heterogeneities in seep fluid flow (Linke et al., 2005). Whether these attached bacteria show preferential attachment to specific substrates that guarantee access to sulfide or other metabolites, or if their distribution is influenced by the very abundant microbial grazers in the system remain open questions.

Examination of photographs and specimens of seep fauna collected during 2005 and 2006 cruises to the Eel River Basin and Hydrate Ridge (off the coast of California and Oregon, USA), and observations of gastropods collected from Hydrate Ridge in 2010 both show inhabitation by morphologically similar elongate Thiomargarita-resembling cells (Figure 2b), suggesting that certain ecotypes of attached sulfur bacteria are geographically widespread in seep settings. The difficulty in collecting these specimens and maintaining them under enrichment conditions that allow for observation of their development renders our understanding of these organisms incomplete. However, the dimorphic life cycle in seep-associated cells closely related to Thiomargarita spp. described here reveals a complex reproductive ecology for these giants of the bacterial world that further confounds the generalization that bacteria are small and simple.

\section{Conflict of interest}

The authors declare no conflict of interest.

\section{Acknowledgements}

This study was funded by the Agouron Institute, the University of Minnesota Department of Geology and Geophysics, the Max Planck Society, and the National
Science Foundation (OCE-0826254 and OCE 09-39557). Parts of this work were carried out in the Characterization Facility, University of Minnesota, a member of the NSFfunded Materials Research Facilities Network (http:// www.mrfn.org) via the MRSEC program with assistance from Chris Frethem and Fang Zhou. Scanning electron microscopy was performed in the University of Minnesota, Twin Cities, Limnological Research Center with the support of Amy Myrbo. Furthermore, we thank Tony Rathburn, Shana Goffredi, Anders Waren, Danwei Huang, Anne Dekas, Olivia Mason, Ben Harrison, the crew of the R/V Atlantis and pilots of the DSV Alvin (15-44 and 15-59) for assistance at sea, and Ben Grupe for providing live gastropods from Hydrate Ridge. We thank the reviewers of this manuscript for valuable comments that helped improve the manuscript.

\section{References}

Alain K, Olagnon M, Desbruyères D, Pagé A, Barbier G, Juniper SK et al. (2002). Phylogenetic characterization of the bacterial assemblage associated with mucous secretions of the hydrothermal vent polychaete Paralvinella palmiformis. FEMS Microbiol Ecol 42: 463-476.

Angert ER. (2005). Alternatives to binary fission in bacteria. Nat Rev Microbiol 3: 214-224.

Bailey JV, Joye SB, Kalanetra KM, Flood BE, Corsetti FA. (2007). Evidence of giant sulphur bacteria in Neoproterozoic phosphorites. Nature 445: 198-201.

Bohrmann G, Heeschen K, Jung C, Weinrebe W, Baranov B, Cailleau B et al. (2002). Widespread fluid expulsion along the seafloor of the Costa Rica convergent margin. Terra Nova 14: 69-79.

Brun YV, Janakiraman R. (2000). The dimorphic life cycle of Caulobacter and stalked bacteria. In: Brun YV and Shimkets LJ (eds). Prokaryotic Development. American Society for Microbiology: Washington, DC, pp 297-317.

Cardinale M, Brusetti L, Quatrini P, Borin S, Puglia AM, Rizzi A et al. (2004). Comparison of different primer sets for use in automated ribosomal intergenic spacer analysis of complex bacterial communities. Appl Environ Microbiol 70: 6147-6156.

Dattagupta S, Schaperdoth I, Montanari A, Mariani S, Kita N, Valley JW et al (2009). A novel symbiosis between chemoautotrophic bacteria and a freshwater cave amphipod. ISME J 3: 935-943.

de Beer D, Sauter E, Niemann H, Kaul N, Foucher J-P, Witte U et al (2006). In situ fluxes and zonation of microbial activity in surface sediments of the Håkon Mosby Mud Volcano. Limnol Oceanogr 51: 1315-1331.

Gillian DC, Dubilier N. (2004). Novel epibiotic Thiothrix bacterium on a marine amphipod. Appl Environ Microbiol 70: 3773-3775.

Girnth A-C, Grünke S, Lichtschlag A, Felden J, Knittel K, Wenzhöfer F et al. (2011). A novel, mat-forming Thiomargarita population associated with a sulfidic fluid flow from a deep-sea mud volcano. Environ Microbiol 13: 495-505.

Gutzke V. (2007). Morphologische und physiologische Untersuchungen an Thiomargarita spp. Diploma thesis, University of Hannover: Germany.

Huettel M, Forster S, Klöser S, Fossing H. (1996). Vertical migration in the sediment-dwelling sulfur bacteria 
Thioploca spp. in overcoming diffusion limitations. Appl Environ Microbiol 62: 1863-186.

Joye SB, Boetius A, Orcutt BN, Montoya JP, Schulz HN, Erickson MJ et al. (2004). The anaerobic oxidation of methane and sulfate reduction in sediments from Gulf of Mexico cold seeps. Chem Geol 205: 219-238.

Karnovsky MJ. (1965). A formaldehyde-glutaraldehyde fixative of high osmolarity for use in electron microscopy. J Cell Biol 27: 137.

Kalanetra KM, Huston SL, Nelson DC. (2004). Novel, attached, sulfur-oxidizing bacteria at shallow hydrothermal vents possess vacuoles not involved in respiratory nitrate accumulation. Appl Environ Microbiol 70: 7487-7496.

Kalanetra KM, Joye SB, Sunseri NR, Nelson DC. (2005). Novel vacuolate sulfur bacteria from the Gulf of Mexico reproduce by reductive division in three dimensions. Environ Microbiol 7: 1451-1460.

Kalanetra KM, Nelson DC. (2010). Vacuolate-attached filaments: highly productive Ridgeia piscesae epibionts at the Juan de Fuca hydrothermal vents. Mar Biol 4: 791-800.

Lane N, Martin W. (2010). The energetics of genome complexity. Nature 467: 929-934.

Linke P, Wallmann K, Suess E, Hensen C, Rehder G. (2005). In situ benthic fluxes from an intermittently active mud volcano at the Costa Rica convergent margin. Earth Planet Sci Lett 235: 79-95.

Ludwig W, Strunk O, Westram R, Richter L, Meier H, Yadhukumar et al. (2004). ARB: a software environment for sequence data. Nucl Acids Res 32: 1363-1371.

Mußmann M, Hu FZ, Richter M, de Beer D, Preisler A, Jørgensen B et al. (2007). Insights into the genome of large sulfur bacteria revealed by analysis of single filaments. PLoS Biol 5: 1923-1937.

Nelson DC, Revsbech NP, Jørgensen BB. (1986). Microoxicanoxic niche of Beggiatoa spp.: a microelectrode survey of marine and freshwater strains. Appl Environ Microbiol 52: 161-168.

Ott JA, Novak R, Schiemer F, Hentschel U, Nebelsick M et al. (1991). Tackling the sulfide gradient: a novel strategy involving marine nematodes and chemoautotrophic ectosymbionts. Mar Ecol 12: 261-279.
Peplies J, Kottmann R, Ludwig W, Glöckner FO. (2008). A standard operating procedure for phylogenetic inference (SOPPI) using (rRNA) marker genes. Syst Appl Microbiol 31: 251-257.

Poindexter JS. (1984). The role of calcium in stalk development and in phosphate acquisition in Caulobacter crescentus. Arch Microbiol 138: 140-152.

Poindexter JS. (2006). Dimorphic prosthecate bacteria: the genera Caulobacter, Asticcacaulis, Hyphomicrobium, Pedomicrobium, Hyphomonas, and Thiodendron. In: Dworkin M (ed.). The Prokaryotes. Springer-Verlag: New York, pp 72-90.

Pruesse E, Quast C, Knittel K, Fuchs BM, Ludwig WG, Peplies J et al. (2007). SILVA: a comprehensive online resource for quality checked and aligned ribosomal RNA sequence data compatible with ARB. Nucl Acids Res 35: 7188-7196.

Salman V, Amann R, Girnth A-C, Polerecky L, Bailey J, Høgslund $\mathrm{S}$ et al. (2011). A single-cell sequencing approach to the classification of large, vacuolated sulfur bacteria. Syst Appl Microbiol 34: 243-259.

Schulz HN. (2006). The genus Thiomargarita. In: Dworkin M (ed.). The Prokaryotes: An Evolving Electronic Resource for the Microbiological Community. Springer-Verlag: New York.

Schulz HN, Brinkhoff T, Ferdelman T, Marine MH, Teske A, Jørgensen BB. (1999). Dense populations of a giant sulfur bacterium in Namibian shelf sediments. Science 284: 493-495.

Schulz HN, Jørgensen BB. (2001). Big bacteria. Annu Rev Microbiol 55: 105-137.

Schulz HN, Schulz HD. (2005). Large sulfur bacteria and the formation of phosphorite. Science 307: 416-418.

Teske A, Sogin ML, Nielsen LP, Jannasch HW. (1999). Phylogenetic position of a large marine Beggiatoa. Syst Appl Microbiol 22: 39-44.

Young KD. (2006). The selective value of bacterial shape. Microbiol Mol Biol Rev 70: 660-703.

Zbinden M, Cambon-Bonavita MA. (2003). Occurrence of Deferribacterales and Entomoplasmatales in the deepsea Alvinocarid shrimp Rimicaris exoculata gut. FEMS Microbiol Ecol 46: 23-30.

Supplementary Information accompanies the paper on The ISME Journal website (http://www.nature.com/ismej) 